Historic, Archive Document

Do not assume content reflects current scientific knowledge, policies, or practices. 

CATALOG OF

\section{Highlands Nursery}

\section{Pineola, North Carolina}

\section{KELSEY'S RHODODENDRONS, AZALEAS, and other Hardy NATIVE AMERICAN PLANTS Grown in the Carolina Mountains at 3,800 feet elevation}

\section{Information}

HIGHLANDS NURSERY SHIPMENTS are made from Pineola, N. C., freight station, and prices in this list are made on this basis. Freight and express rates gladly quoted. Via Norfolk steamship lines, deliveries to northern and eastern points are quick and rates are low.

SHIPMENTS OF "COLLECTED" RHODODENDRON MAXIMUM and KALMIAS are from my special fields in Pennsylvania and the South, depending on destination and quality of stock desired. The best clumps come from the South, from high altitudes. "COLLECTED" RHODODENDRON CATAWBIENSE comes only from the South.

MY NURSERIES ARE UNIQUE, being the first to grow Native American Ornamentals, and having the only large and complete stock of Hardy American Plants in existence.

SHIPPING BEGINS IN SEPTEMBER, when I send out large Rhododendrons, Kalmias and other evergreens, and bulbs and herbaceous plants, general stock going out in October and November; and in spring from about March 1 to May 15 . Give shipping instructions, unless you wish to leave it to me, when I use my best judgment, but assume no risk.

EXPORT SHIPMENTS reach the most remote countries in perfect condition; I have exported for over twenty-five years, and know how to pack.

DESCRIPTIVE CATALOGS, beautifully illustrated, are mailed on request, and advice on the right way to grow Rhododendrons, Azaleas and other native plants is gladly given. Send for "How to Grow Rhododendrons Successfully." Always address 


\section{Catalog of HIGHLANDS NURSERY}

At my Highland Nursery, Pineola, North Carolina, 3,800 ft. elevation, on the crest of the Alleghany Mountains, one may see Rhododendrons, Azaleas, Leucothoës, Kalmias and Andromedas growing in all sizes by tens of thousands in single species, and nowhere else can be found such a collection of rare American plants of unquestionable hardiness - the best for American gardens.

The Carolina Mountains is the native home of the most beautiful Broad-leaved Evergreens and Ericaceous Shrubs. Highlands Nursery not only ships direct to customers, but is a great propagating plant, supplying material for my Boxwood Nursery.

\section{DECIDUOUS AND EVERGREEN Trees, Shrubs and Woody Vines}

NOTE.-All plants are transplanted and nursery-grown, unless plainly marked otherwise.

This is a catalog of nursery-grown plants growing at my Highlands Nursery, Pineola, North Carolina.

*Abies concolor. 6 to 12 in

$\begin{array}{llll}\text { Each } & 10 & 100 & 1,000\end{array}$

* Abies fraseri. 6 to 12 in....... 15 to $2 \mathrm{ft} . \ldots \ldots \ldots$ 2 to $3 \mathrm{ft} . \ldots \ldots \ldots \ldots \ldots \ldots . .6 \%$

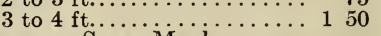

$\$ 125 \$ 1000$

$\begin{array}{lrlrl}75 & 6 & 00 & \$ 50 & 00\end{array}$

$\begin{array}{llllll}2 & 00 & 18 & 00 & 150 & 00\end{array}$

1250

4000

Acer saccharum. Sugar Maple.

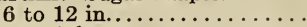

1 to $2 \mathrm{ft}$. .

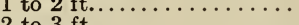

2 to $3 \mathrm{ft}$

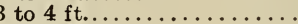

4 to $6 \mathrm{ft}$.

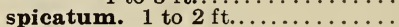
2 to $3 \mathrm{ft}$.

3 to $4 \mathrm{ft}$

Adelia acuminata. 2 to $3 \mathrm{ft} . \ldots \ldots \ldots$

Esculus octandra. 6 to 12 in., seedlings. 1 to 2 ft....................

Alnus alnobetula.

rugosa. 2 to $3 \mathrm{ft} . \ldots \ldots \ldots \ldots \ldots$.

Amelanchier botryapium. 1 to 2 to $3 \mathrm{ft}$.

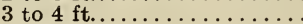

4 to $6 \mathrm{ft}$.

6 to $8 \mathrm{ft}$.

Amorpha fruticosa. 2 -yr. seedlings...

Ampelopsis quinquefolia engelmanni.

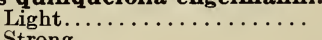

*Andromeda (Pieris) floribunda. Mountain Fetter Bush. 6 to 12 in............ 1100
1 to $11 / 2 \mathrm{ft} . \ldots \ldots \ldots \ldots \ldots \ldots \ldots$
$11 / 2$ to $2 \mathrm{ft} . \ldots \ldots \ldots \ldots \ldots \ldots$

$\begin{array}{llll}8 & 00 & 70 & 00\end{array}$

$1250 \quad 10000$

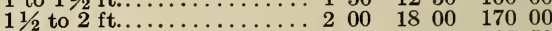

Aralia spinosa. 1 to $2 \mathrm{ft} \ldots \ldots \ldots \ldots \ldots \ldots 25 \quad 150 \quad 1250$

Aronia arbutifolia. 6 to 12 in........ $20 \quad 125 \quad 1000$ 1 to $2 \mathrm{ft} . \ldots \ldots \ldots \ldots \ldots \ldots \ldots . \ldots \ldots$

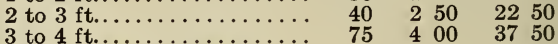
erythrocarpa, Dwari variety. 1 to 2 ft............... $35 \quad 200$ 2 to 3 ft..................... $50 \quad 300$

nigra. Shining black fruit. 1 to $2 \mathrm{ft}$. $20 \quad 125 \quad 1000$ 2 to $3 \mathrm{ft} . \ldots \ldots \ldots \ldots \ldots \ldots \ldots . \ldots 35 \quad 200 \quad 1750$

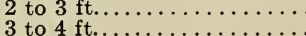

\section{AZALEAS}

Azalea arborescens. F ra Each grant White. 6 to 12 in... $\$ 035$ 1 to $1 \frac{1}{2} \mathrm{ft} . \ldots \ldots \ldots \ldots \ldots \ldots .6 \ldots$ $11 / 2$ to $2 \mathrm{ft}$

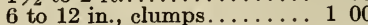
6 to 12 in., clumps............ 1 to 1125 $11 / 2$ to $2 \mathrm{ft}$., clumps.......... 200 2 to $3 \mathrm{ft}$. clumps.......... $4 \quad 00 \quad 3000$

Azalea lutea Great FlameAzalea.

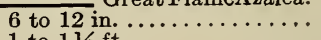

1 to $11 / 2 \mathrm{ft} . \ldots \ldots \ldots \ldots \ldots \ldots \ldots$

$11 / 2$ to $2 \mathrm{ft}$.

2 to $3 \mathrm{ft}$..

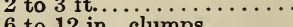

6 to 12 in., clumps........

1 to $11 / 2 \mathrm{ft}$., clumps........ 75

$11 / 2$ to $2 \mathrm{ft}$., clumps.......... 100

$\begin{array}{lllllll}25 & 1 & 50 & 12 & 50 & \$ 100 & 00\end{array}$ $\begin{array}{lllllll}40 & 2 & 50 & 22 & 50 & 200 & 00\end{array}$

$\begin{array}{llllll}3 & 00 & 25 & 00 & 225 & 00\end{array}$ 
Catalog of HIGHLANDS NURSERY

TREES, SHRUBS AND WOODY VINES, continued

Azalea nudiflora. Pinxter Flower. Each $10 \quad 100 \quad 1,000$

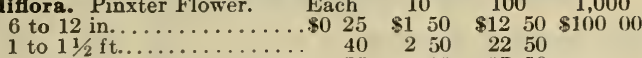

1 to $11 \% \mathrm{ft}$. clumps........... $75 \quad 400 \quad 3750$

Azalea vaseyi. Southern Azalea.

viscosa. $\begin{aligned} & 1 \text { to } 11 / 2 \mathrm{ft} \ldots \ldots \ldots \ldots \ldots \ldots \ldots \\ & 6 \text { to } 12\end{aligned}$

1 to $11 / 2 \mathrm{ft}$

1 to $11 / 2 \mathrm{ft}$., climins.

$11 / 2$ to $2 \mathrm{ft}$., clumps.

...... 100

Benzoin benzoin. 1 to $2 \mathrm{ft} \ldots \ldots . .1$

Betula lenta. 6 to $8 \mathrm{ft}$. . . . . . . .

8 to $10 \mathrm{ft}$.

Calycanthus fertilis. 2 to $3 \mathrm{ft}$, clumps.

floridus. 1 to $2 \mathrm{ft}$.

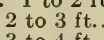

Carpinus caroliniana (americana).

4 to $6 \mathrm{ft}$. 6 to $8 \mathrm{ft}$. Chinkapin. i to $2 \mathrm{ft}$ 2 to $3 \mathrm{ft}$. .

Chinkapin. 1 to $2 \mathrm{ft}$ 3 to $4 \mathrm{ft} . \ldots \ldots \ldots \ldots \ldots \ldots$

Celastrus punctatus. 1 to $2 \mathrm{ft}$.......... 2 to $3 \mathrm{ft}$

candens. 6 to 12 in. 1 to $2 \mathrm{ft}$.

Cephalanthus 3 ft......... 3 to 4 . 4 to $5 \mathrm{ft}$.

Chamædaphne calyculata. 6 to 12 in. 1 to $11 / 2 \mathrm{ft}$..

Chionanthus virginica. 1 to $2 \mathrm{ft}$........ Clethra acuminata. Southern Pepper Bush. 1 to $2 \mathrm{ft} . . \ldots \ldots \ldots$. 2 to $3 \mathrm{ft}$.

4 to $6 \mathrm{ft}$.

alnifolia. Sweet Pepper Bush.

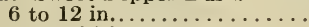
1 to $11 / 2 \mathrm{ft}$.

Comptonia peregrina (asplenitolia).

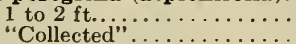

Cornus amomum (sericea). 3 to $4 \mathrm{ft}$.

Corylus americana. 1 to $2 \mathrm{ft}$.......... 2 to $3 \mathrm{ft} . \ldots \ldots \ldots \ldots \ldots \ldots \ldots \ldots \ldots \ldots$

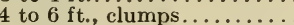

rostrata. 1 to $2 \mathrm{ft} . \ldots \ldots \ldots \ldots \ldots$ 2 to $3 \mathrm{ft}$.

3 to $4 \mathrm{ft}$. clumps.

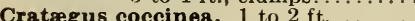

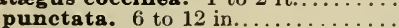
1 to $2 \mathrm{ft} . \ldots \ldots \ldots \ldots \ldots \ldots \ldots \ldots \ldots \ldots \ldots \ldots \ldots$

Pecodon verticillatus. 1 to $2 \mathrm{ft} . . . . .$. Dendrium buxifolium. 3 to 6 in., clumps (i) to 12 in., clumps........

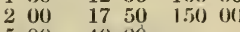

$500 \quad 4000$

6005000

$150 \quad 1200$

300

600

$\begin{array}{llll}1 & 50 & 12 & 00\end{array}$

$\begin{array}{llll}25 & 200 & 1500\end{array}$

$\begin{array}{llll}150 & 1 & 25 & 600\end{array}$

$40-250 \quad 2000$

$\begin{array}{lllll}30 & 2 & 00 & 15 & 00\end{array}$

$\begin{array}{lllll}50 & 3 & 00 & 25 & 00\end{array}$

$\begin{array}{lllll}30 & 2 & 00 & 17 & 50\end{array}$

$\begin{array}{lllll}40 & 3 & 00 & 25 & 00 \\ 60 & 4 & 50 & 40 & 00\end{array}$

$20100 \quad 850$

$25150 \quad 1250$

$\begin{array}{lllll}35 & 2 & 00 & 18 & 00\end{array}$

$\begin{array}{lllll}20 & 1 & 00 & 8 & 50\end{array}$

$\begin{array}{lllll}25 & 1 & 50 & 12 & 50\end{array}$

\section{Dendrium prostratum.}

Diervilla diervilla (trifida). 6 to 12 in. rivularis. 1 to $2 \mathrm{ft}$.

sessilifolia. 1 to $2 \mathrm{ft}$.

Euonymus americanus. 3 to $4 \mathrm{ft} \ldots$

Fraxinus americana. 2 to $3 \mathrm{ft} . \ldots \ldots$. 3 to $4 \mathrm{ft}$.

lanceolata (viridis). 4 to $6 \mathrm{ft}$........ (i) to $8 \mathrm{ft}$.

oregona. 1 to $2 \mathrm{ft}$

Gaylussacia resinosa. 6 to 12 in....... 1 to $2 \mathrm{ft} . \ldots \ldots \ldots \ldots \ldots \ldots$

ursina. 1 to $2 \mathrm{ft}$, clumps......

Halesia tetraptera (carolinum). 6 to 12 in., seedlings........ 2 to $3 \mathrm{ft}$.

2 to $3 \mathrm{ft} . \ldots \ldots \ldots \ldots \ldots \ldots$ 3 to $4 \mathrm{ft}$

Hydrangea arborescens. 1 to $2 \mathrm{ft}$., clp.

*Hypericum a 2 to $3 \mathrm{ft}$., clumps........... 6 to $12 \mathrm{in}$., seedl'g. 1 to $2 \mathrm{ft}$.

$\begin{array}{llll}3 & 00 & 25 & 00\end{array}$

$125 \quad 1000$

$150 \quad 1200$

$\begin{array}{llll}2 & 00 & 16 & 00\end{array}$

300

300

100

150

2001500

$100 \quad 850$

$150 \quad 1250$

250

$100 \quad 800$ 
TREES, SHRUBS AND WOODY VINES, continued

* Eypericum densifiorum. 1 to $2 \mathrm{ft}$. . $\$ 0 \quad 15 \quad \$ 0 \quad 75 \quad \begin{array}{llll}\text { Each } & 10 & 100 & 1,000\end{array}$

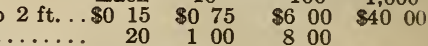

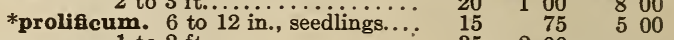

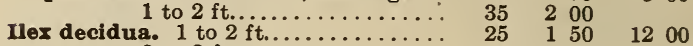

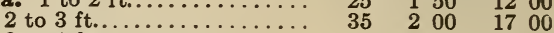

$\begin{array}{rlllll}3 \text { to } 4 \text { ft.................... } & 50 & 300 & 27 & 00\end{array}$

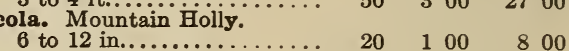

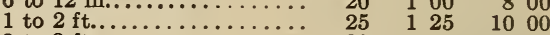

2 to $3 \mathrm{ft} . \ldots \ldots \ldots \ldots \ldots \ldots$

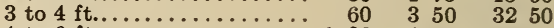

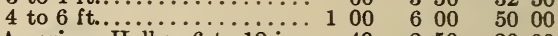

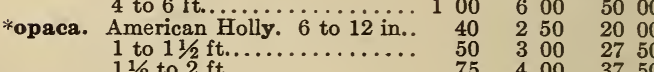

$11 / 2$ to 2 ft............... 75

verticillata. 1 to 2 ft............. 30

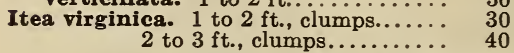

* Juniperus virginiana. ${ }^{6}$ to $12 \mathrm{in} .20$

800

800

200

$175 \quad 1500$

$\begin{array}{llll}3 & 00 & 20 & 00\end{array}$

1251000

\section{KALMIAS (The Mountain Laurel)}

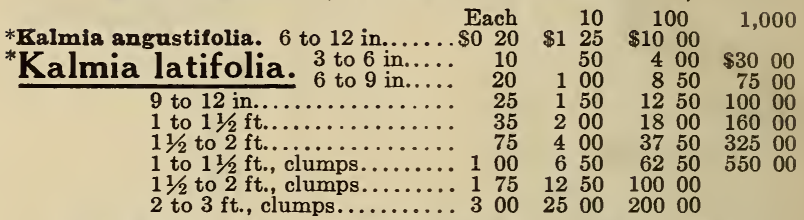

"COLLECTED" KALMIA LATIFOLIA. For prices and full information, see page 9.

\section{*Leucothoe catesbaei.}

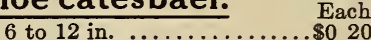

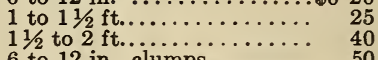

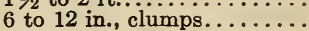

1 to $11 / 2 \mathrm{ft}$. , clumps.......... 75

$11 / 2$ to $2 \mathrm{ft}$., clumps........ 100

2 to $3 \mathrm{ft}$. clumps............... 150

*recurva. 6 to 12 in.............. 20

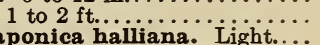

Lonicera japonica halliana. Light...

$\checkmark$ Magnolia fraseri. 2 to $3 \mathrm{ft} \ldots \ldots \ldots \ldots \ldots \ldots$

tripetala. 3 to $4 \mathrm{ft} \ldots \ldots \cdots \cdots \cdots \cdots \cdots$
Malus coronaria. Wild Fragrant Crab. 6 to 12 in., seedlings.........

Menziesia pilosa. 1 to $2 \mathrm{ft}$., clumps...

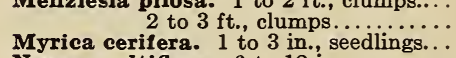

Nyssa multiflora. 6 to 12 in.......... 1 to $2 \mathrm{ft} . \ldots \ldots \ldots \ldots \ldots \ldots \ldots$ 2 to $3 \mathrm{ft}$.

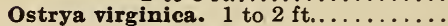
2 to $3 \mathrm{ft} . \ldots \ldots \ldots \ldots \ldots \ldots \ldots$ 3 to $4 \mathrm{ft} . \ldots \ldots \ldots \ldots \ldots \ldots$

Oxydendron arboreum. 6 to 12 in 1 to $2 \mathrm{ft}$.

2 to $3 \mathrm{ft}$

3 to $4 \mathrm{ft} . . .$. 4 to $5 \mathrm{ft}$.

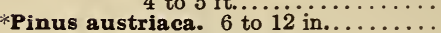
1 to $11 / 2 \mathrm{ft} . \ldots \ldots \ldots \ldots \ldots$

*banksiana (divaricata). 2 to $3 \mathrm{ft}$... 3 to $4 \mathrm{ft} . \ldots \ldots \ldots \ldots \ldots \ldots \ldots$ 4 to $6 \mathrm{ft} . \ldots \ldots \ldots \ldots \ldots \ldots$ 6 to $8 \mathrm{ft}$.

10

$\$ 100$

150

275

300

400

650

200

100

200

100

150

150

400

250

100

150

200

350

60

100

250

400

$\begin{array}{ll}1 & 25 \\ 2 & 00\end{array}$

$\begin{array}{ll}2 & 00 \\ 3 & 00\end{array}$

100

150

225

350

500

250

400

200

250

250

$\begin{array}{ll}5 & 00 \\ 6 & 00\end{array}$

$\begin{array}{ll}6 & 00 \\ 3 & 00\end{array}$

150

175

600

100

200

300

500

100

$\begin{array}{ll}1 & 00 \\ 1 & 50\end{array}$

$100 \quad 1,000$

$\begin{array}{llll} & 50 & \$ 75 & 00\end{array}$ 125010000

1500

$27 \quad 50 \quad 22500$

$\begin{array}{llll}50 & 325 & 00\end{array}$

6250

10000

800

1500

$\begin{array}{rr}6 & 00 \\ 8 & 50\end{array}$

200

5000

7500

2000

800

1200

1750

3000

500

800
2000

1000

1750

$\begin{array}{llll}8 & 50 & 75 & 00\end{array}$

$1200 \quad 9000$

$\begin{array}{llll}20 & 00 & 180 & 00\end{array}$

3000

4500

2000

3000

1600

$3000 \quad 20000$

$\begin{array}{llll}50 & 00 & 300 & 00\end{array}$

1000

500

5000

$\begin{array}{rr}7 & 00 \\ 16 & 00\end{array}$

2750

4500

4000

6000

$$
4 \text { to } 6 \mathrm{ft} \text {. }
$$

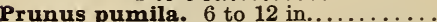
1 to $2 \mathrm{ft}$.............. Douglas Spruce.

1 to 3 in., transplanted....

3 to 6 in., transplanted...... 


\section{RHODODENDRONS}

\section{*Rhododendron ca rolini- Each $10 \quad 100$ \\ anum. 6 to 9 in., nursery-grown. . \$o $40 \quad \$ 2 \quad 50 \quad \$ 22 \quad 50$ \\ 6 to 9 in., clumps, nursery- $100 \quad 700 \quad 6500$ \\ 9 to 12 in., clumps, nursery- \\ grown....... $150 \quad 1000 \quad 9000$ \\ 1 to $11 / 2 \mathrm{ft} .$, clumps, nursery- \\ $\begin{array}{llllll}1 & 75 & 12 & 50 & 110 & 00\end{array}$}

1,000

*catawbiense.

3 to 6 in., heavy, nursery-grown... $\quad 20 \quad 100 \quad 8 \quad 50 \quad \$ 7500$ 6 to 9 in., heavy, nursery-grown... $25 \quad 150 \quad 1250 \quad 10000$ 9 to 12 in., heavy, nursery-grown.. $35 \quad 200 \quad 1800$

1 to $11 / 2 \mathrm{ft}$., clumps, nursery-grown. $150 \quad 1000 \quad 9000 \quad 750 \quad 00$ $1 \frac{1}{2}$ to $2 \mathrm{ft}$., clumps, nursery-grown. $200 \quad 1600 \quad 13500130000$ 2 to $3 \mathrm{ft}$., clumps, nursery-grown... $30002500 \quad 20000 \quad 1750 \quad 00$ 3 to $4 \mathrm{ft}$., clumps, nursery-grown... $500 \quad 4000 \quad 37500$

4 to $5 \mathrm{ft}$., clumps, nursery-grown... $700 \quad 6000$

*maximum. The Great American

maximum. Rosebay

3 to 6 in., nursery-grown... . . . . . .

6 to 9 in., nursery-grown.

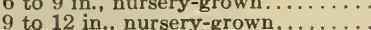

1 to $11 / 2 \mathrm{ft}$, nursery-grown.

$11 / 2$ to 2 ft. nursery-grown.

$11 / 2$ to $2 \mathrm{ft}$. , nursery-grown....... 75

9 to 18 in., clumps, nursery-grown.. 125

$\begin{array}{llll}11 / 2 & \text { to } 2 \mathrm{ft} \text {., clumps, nursery-grown } 1 & 50 \\ 2 & \text { to } 3 \mathrm{ft} \text {., clumps, nursery-grown... } 2 & 25\end{array}$

3 to $4 \mathrm{ft}$., clumps, nursery-grown... 400

5 to $6 \mathrm{ft}$, clumps, nursery-grown... $800 \quad 7000$

"Collected" Rhododendrons. I supply the finest "collected" clumps of Rhododendron maximum and $\mathbf{R}$. catawbiense by the carload and by the thousand. For prices and full information, see page 9.

Rhus aromatica (canadensis). 1 to $3 \mathrm{ft} \quad$ Each $10 \quad 100$

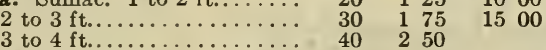

cotinoides. Southern Smoke Tree. 3 to $4 \mathrm{ft} . \ldots \ldots \ldots \ldots \ldots \ldots \ldots 150$

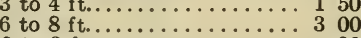

glabra. 2 to 3 ft............... 20

typhina (hirta). 1 to $2 \mathrm{ft} . \ldots \ldots \ldots . . .20$ 2 to $3 \mathrm{ft} . \ldots \ldots \ldots \ldots \ldots \ldots$ 4 to $6 \mathrm{ft}$.

Ribes cynosbati. 1 to $2 \mathrm{ft}$

ibes cynosbati. 1 to $2 \mathrm{ft} . \ldots \ldots \ldots \ldots$
rotundifolium. 2 to $3 \mathrm{ft} . \ldots \ldots \ldots \ldots$ binia hispida. 1 to $2 \mathrm{ft} . \ldots \ldots \ldots \ldots$ velseyi. 1 to $2 \mathrm{ft}$.

1,000

roga arkansana 1 to $2 \mathrm{ft} \ldots \ldots . . . .$.

blanda. 1 to 2 ft.

caroling. 1 to $2 \mathrm{ft} . . . . . .$. 2 to $3 \mathrm{ft}$.

1 to $2 \mathrm{ft} . \ldots \ldots \ldots \ldots \ldots \ldots \ldots \ldots$

lucida. 1 to $2 \mathrm{ft}$.

nitida. 6 to 12 in

$$
1 \text { to } 2 \mathrm{ft} \text {. }
$$

rubiginosa. 1 to $2 \mathrm{ft}$., seedlings..........

Rubus canadensis. 1 to $3 \mathrm{ft}$...........

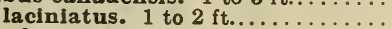
odoratus. 1 to $2 \mathrm{ft}$.

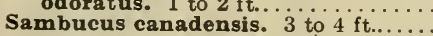
racemosus (pubens). 1 to $2 \mathrm{ft} . .$.

Spirza tomentosa alba. 1 to $2 \mathrm{ft}$.....

Stuartia pentagyna. Southern Stuartia.

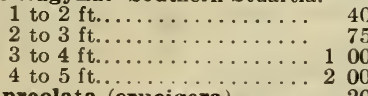

Tecoma capreolata (crucigera)...... 20 grandiflora. Strong............. 6

\section{HEMLOCKS}

${ }^{*}$ Tsuga canadensis. Canadian Each 
TREES, SHRUBS AND WOODY VINES, continued

*Tsuga caroliniana. Ca rolina Each $10 \quad 100 \quad 1.000$

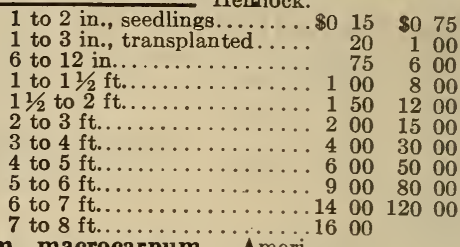

$\$ 500 \quad \$ 40 \quad 00$

5000

7000

to $8 \mathrm{ft} . \ldots \ldots \ldots \ldots \ldots \ldots \ldots \ldots$

*Vaccinium macrocarpum. Ameri-

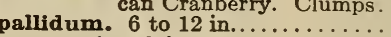

1 to $2 \mathrm{ft}$.

1 to $2 \mathrm{ft}$., clumps.

2 to 3 ft., clumps...

pennsyivanicum. 3 to 6 . $11 / 2 \mathrm{ft}$. . 1 to $11 / 2 \mathrm{ft}$., clumps. $11 / 2$ to $2 \mathrm{ft}$., clumps

acerifolium 6 to 12 ........ 1 to $2 \mathrm{ft}$.

$\ln i t_{0}$

$$
2 \text { to } 3 \mathrm{ft} \text {. . }
$$

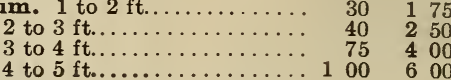

\section{Viburnum cassinoides.}

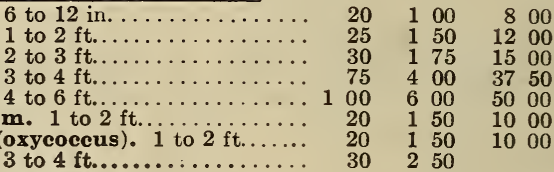

1000

opulus (oxycoccus). 1 to $2 \mathrm{ft} . \ldots \ldots .20 \quad 20 \quad 150$

Xanthorrhiza apiifolia.

$\begin{array}{rrrrr} & 75 & 5 & 00 \\ 2 & 00 & 17 & 50 \\ 3 & 00 & & \\ 4 & 00 & 30 & 00 \\ 6 & 00 & 50 & 00 \\ 1 & 75 & 15 & 00 \\ 2 & 00 & 16 & 00 \\ 3 & 50 & 30 & 00 \\ 5 & 00 & 40 & 00 \\ & 75 & 5 & 00 \\ 1 & 25 & 10 & 00 \\ 2 & 00 & 18 & 00 \\ 1 & 75 & & \\ 2 & 50 & & \\ 4 & 00 & & \\ 6 & 00 & & \\ & & & \\ & & & \\ 1 & 00 & & 8 & 00 \\ 1 & 50 & & 12 & 00 \\ 1 & 75 & & 15 & 00 \\ 4 & 00 & & 37 & 50 \\ 6 & 00 & & 50 & 00 \\ 1 & 50 & & 10 & 00 \\ 1 & 50 & 10 & 00 \\ 2 & 50 & & \end{array}$

Yellow Root. 3 to 6 in... 6 to 12 in.

3 to 6 in., clumps.

6 to 12 in., clumps.

1 to $11 / 2 \mathrm{ft}$, clumps.......

$11 / 2$ to $2 \mathrm{ft}$., clumps.

Xolisma ligustrina. 1 to $2 \mathrm{ft} . \ldots \ldots \ldots$.

$\begin{array}{rrrrrrr}10 & & 50 & 4 & 00 & 30 & 00 \\ 15 & & 75 & 5 & 00 & 40 & 00 \\ 20 & 1 & 00 & 6 & 00 & 50 & 00 \\ 25 & 1 & 25 & 8 & 00 & 70 & 00 \\ 35 & 2 & 50 & 18 & 00 & 150 & 00 \\ 50 & 4 & 00 & 30 & 00 & & \\ 20 & 1 & 50 & 12 & 00 & & \end{array}$

\section{Hardy Herbaceous Perennials, Vines,} Aquatics, Ferns, Orchids, Lilies and Bulbous Plants 
Catalog of HIGHLANDS NURSERY

HARDY HERBA CEOUS PERENNIALS, continued

Polygonatum biflorum

\begin{tabular}{|c|c|c|c|c|c|c|}
\hline Each & 10 & & 10 & & 1,00 & \\
\hline \$0 15 & $\$ 0$ & 75 & $\$ 6$ & 00 & & \\
\hline 20 & 1 & 00 & 8 & 00 & & \\
\hline 20 & 1 & 00 & 8 & 00 & & \\
\hline 20 & 1 & 00 & 8 & 00 & & \\
\hline & & 00 & 8 & 00 & $\$ 60$ & 00 \\
\hline 15 & & 75 & 6 & 00 & 36 & 00 \\
\hline 30 & 1 & 75 & 15 & 00 & & \\
\hline 25 & 1 & 50 & 12 & 00 & & \\
\hline $\begin{array}{l}25 \\
20\end{array}$ & $\begin{array}{l}1 \\
1\end{array}$ & $\begin{array}{l}50 \\
00\end{array}$ & 8 & 00 & & \\
\hline 35 & 2 & 00 & 18 & 00 & & \\
\hline 75 & 4 & 00 & 35 & 00 & & \\
\hline 20 & 1 & 00 & 8 & 00 & & \\
\hline 20 & 1 & 25 & 10 & 00 & & \\
\hline 20 & 1 & 00 & 8 & 00 & 65 & 00 \\
\hline 50 & 3 & 00 & 20 & 00 & & \\
\hline 15 & & 75 & 6 & 00 & & \\
\hline 20 & 1 & 00 & 8 & 00 & 60 & 00 \\
\hline 25 & 1 & 50 & 12 & 50 & 100 & 00 \\
\hline 50 & 3 & 00 & 26 & 00 & & \\
\hline 20 & 1 & 00 & 8 & 00 & & \\
\hline 20 & 1 & 00 & 8 & 00 & & \\
\hline $\begin{array}{l}10 \\
20\end{array}$ & 1 & $\begin{array}{l}60 \\
00\end{array}$ & $\begin{array}{l}5 \\
8\end{array}$ & $\begin{array}{l}00 \\
00\end{array}$ & & \\
\hline 10 & & 40 & 3 & 00 & 18 & 00 \\
\hline 15 & & 75 & 5 & 00 & 30 & 00 \\
\hline 20 & 1 & 00 & 8 & 00 & & \\
\hline 0 & & 30 & 1 & 50 & & \\
\hline 1 & & 60 & 3 & 50 & 20 & 00 \\
\hline 15 & & 75 & 6 & 00 & 50 & 00 \\
\hline 10 & & 60 & 4 & 00 & 30 & 00 \\
\hline 15 & & 60 & $\begin{array}{l}6 \\
4\end{array}$ & 00 & $\begin{array}{l}50 \\
30\end{array}$ & 00 \\
\hline 15 & & 75 & $\begin{array}{l}4 \\
6\end{array}$ & 00 & 40 & 00 \\
\hline 20 & 1 & 00 & 8 & 00 & & \\
\hline 20 & 1 & 00 & 8 & 00 & & \\
\hline 20 & 1 & 00 & 8 & 00 & & \\
\hline 2 & 1 & 00 & 8 & 00 & & \\
\hline 2 & 1 & 00 & & & & \\
\hline 20 & 1 & 00 & 8 & 00 & & \\
\hline 20 & 1 & 00 & 8 & 00 & & \\
\hline & 1 & $\begin{array}{l}00 \\
75\end{array}$ & 8 & 00 & & \\
\hline 30 & 1 & $\begin{array}{l}75 \\
00\end{array}$ & $\begin{array}{r}14 \\
8\end{array}$ & 00 & & \\
\hline 20 & 1 & 00 & & & & \\
\hline 3 & 2 & 00 & 15 & 00 & & \\
\hline 2 & 1 & 00 & 8 & 00 & 60 & 00 \\
\hline 25 & 1 & 50 & 12 & 50 & & \\
\hline
\end{tabular}

commutatum (Gilenia) stipulacea....

Rotentilla tridentata.

Sanguinaria canadensis. Bloodroot. Strong.

Sanguinaria is shipped entirely at consignee's risk.

* Saracenia flava.

Saxifraga micranthidifolia michauxii

Sedum telephoides and ternatum.

*Shortia galacifolia. 2nd size.......

1st size.

virginica.

Solidago canadensis, bootti, erecta, glomerata, odora, pallida, patula, rugosa and pubens.

Spigelia marilandica.

Steironema ciliatum, quadrifolium and terrestris.

Stenanthium robustum. Mountain Feather Fleece. 3rd size.......... 2nd size.

Stokesia cyanea.

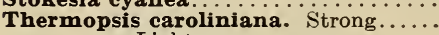
Light.

Tradescantia montana.

Trillium erectum. 2nd size. 1st size.

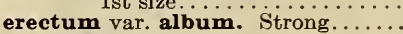
grandiflorum. 2nd size. 1 st size.

recurvatum

stylosum. 2nd size.

$$
\text { 1st size. }
$$

undulatum. 2nd size.

1st size.

Uvularia perfoliata and sessilifolia...

Vagneria racemosa.

Veratrum viride.

Vinca minor. Strong.

Viola canadensis.

cucullata.

hastata.

pedata.

pedata bicolor

rotundifolia.

sagittata.

*Xerophyllum asphodeloides

* Yucca flaccida.

*glauca.

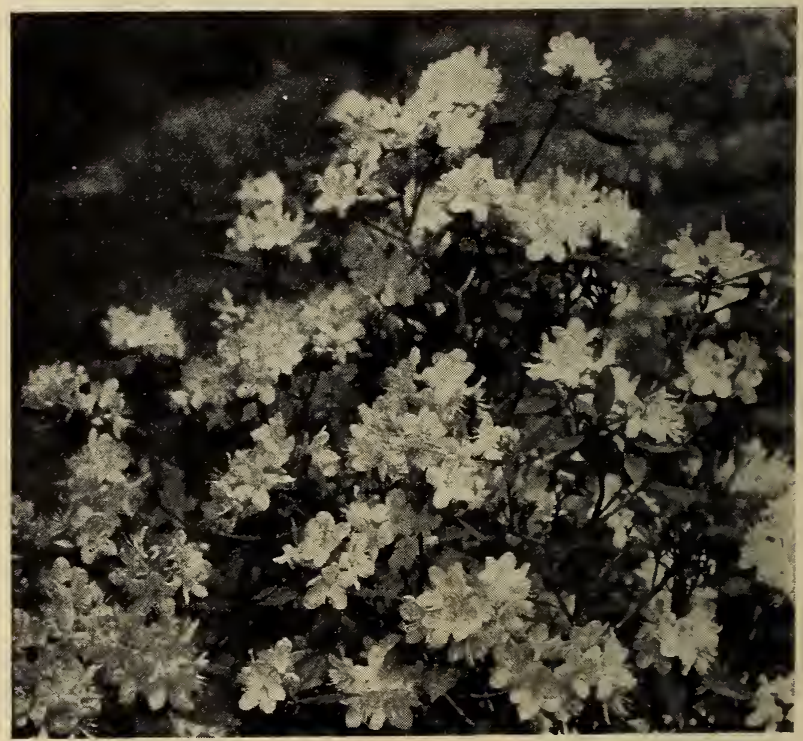

Rhododendron carolinianum

EVERGREENS ARE MARKED WITH A STAR (*) 


\section{Rhododendrons and Mountain Laurel}

\section{"COLLECTED" CLUMPS}

\section{BY THE CARLOAD}

For the area covered and effect produced, a carload of Rhododendrons or Kalmias, offered below, is the cheapest landscape proposition offered. I ship an unusual grade of splendid clumps, each plant a specimen and burlaped separately. Don't accept cheap stock, thrown into cars without laped separately. Don't accept cheap stock, thrown into cars without
burlaping, and with the fine, hair-like rootlets inevitably exposed. You will be disappointed and find it expensive in the end. While fine results may be had from "collected" Rhododendrons, particularly if purchased from a reliable source, where greatest care is used in digging and handling, results are never so sure as when nursery-grown stock is used. "Collected" Rhododendrons and Kalmias delivered at your station by the carload. To be shipped from point determined by me.

\section{Rhododendron catawbiense "Collected"}

Each plant collected from the open and burlaped. Prices, delivered

o. b. your station, if east of the Mississippi river.

Car containing 200 clumps, 1 to $31 / 2 \mathrm{ft}$, for.............\$280 00

Car containing 300 clumps, 1 to $31 / 2 \mathrm{ft}$, for................. 38000

- Car containing 400 clumps, 1 to $31 / 2 \mathrm{ft}$., for................... 48000

Car containing 600 clumps, 1 to $3 \frac{1}{2} \mathrm{ft}$., for.................... 60000

Other combinations and sizes quoted on request.

\section{Rhododendron maximum "Collected"}

Prices in carload lots, delivered f. o. b. your station, if east of the Mississippi River, collected from open ground, and each spccimen burlaped separately.

Car containing 300 clumps, $11 / 2$ to $4 \mathrm{ft}$., for.............\$300 00

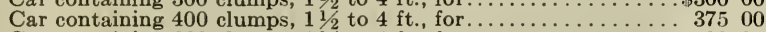
Car containing 600 clumps, $11 \frac{1}{2}$ to $4 \mathrm{ft}$., for............. 50000

Other sizes or combinations will be made up to suit customers. It is far cheaper to buy my kind at slightly increased price, and have plants that will grow.

\section{Rhododendron maximum and}

\section{R. catawbiense}

\section{"Collected" Clumps by the Carload}

Mixed cars, delivered free at any station east of the Mississippi River. Car containing 150 maximum and 150 catawbiense, collected as above, $11 / 2$ to $4 \mathrm{ft}$., clumps, - total of 300 -for $\$ 400$. Car containing 250 maximum and 250 catawbiense, $1 \frac{1}{2}$ to $4 \mathrm{ft}$., clumps,-total of 500 -for $\$ 550$.

\section{Kalmia latifolia (Mountain Laurel)}

\section{"Collected" Clumps by the Carload}

Each specimen burlaped, and highest-class clumps collected from the open, delivered free at your station, if east of the Mississippi River.

Car containing 400 clumps, 1 to $31 / 2 \mathrm{ft}$. for $\$ 375$. Kalmia may be added to help fill any Rhododendron car at 90 cts. per clump, not less than 100 clumps in shipment.

The above "Carload" offers are made with a view of furnishing a variety of sizes that will permit of naturalistic grouping.

"Collected" Rhododendrons and Kalmia by the 100 and 1,000 . The number that may be shipped in a car varies largely, depending on sizes. The minimum weight allowed per car is $16,000 \mathrm{lbs}$., with a freight rate to New York of $\$ 96$.

A car may easily be loaded much heavier, with proportionate increased freight charge, but not increasing the cost per plant.

A full car travels safer than one with a small load. All "Clumps" offered below are collected with a good ball and are burlaped separately.

Prices of "Collected" Clumps of Rhododendrons and Kalmias

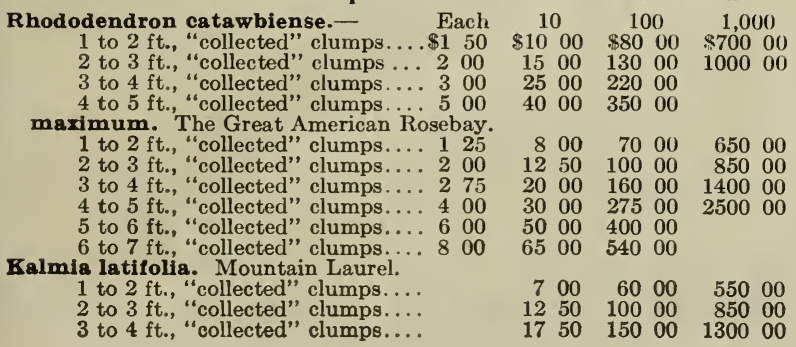




\section{TERMS}

TERMS cash, or satisfactory references from unknown parties. Accounts due the first of each month, unless by special arrangement. 5 at 10 rates; 50 at 100 rates; 500 at 1,000 rates.

AN EXTRA CHARGE is always made for special selection. PACKING free at prices in this catalog.

SEND FOREIGN REMITTANCES by Postal Money Order, drawn on Salem, Mass., post office; or by New York or Boston Exchange. An American dollar equals four shillings, four marks, or five francs.

\section{GUARANTEE}

No guarantee, expressed or implied, is made that stock will grow whether planted by me or not.

Having no control over after treatment of plantings, or over weather conditions, it is obvious that purchaser must assume all responsibility after delivery in good condition.

All shipments travel at consignee's risk, and transportation companies must be held liable for damage in transit.

Claims for errors must be made on receipt of goods. If there is any mistake or fault on my part it will, gladly be rectified.

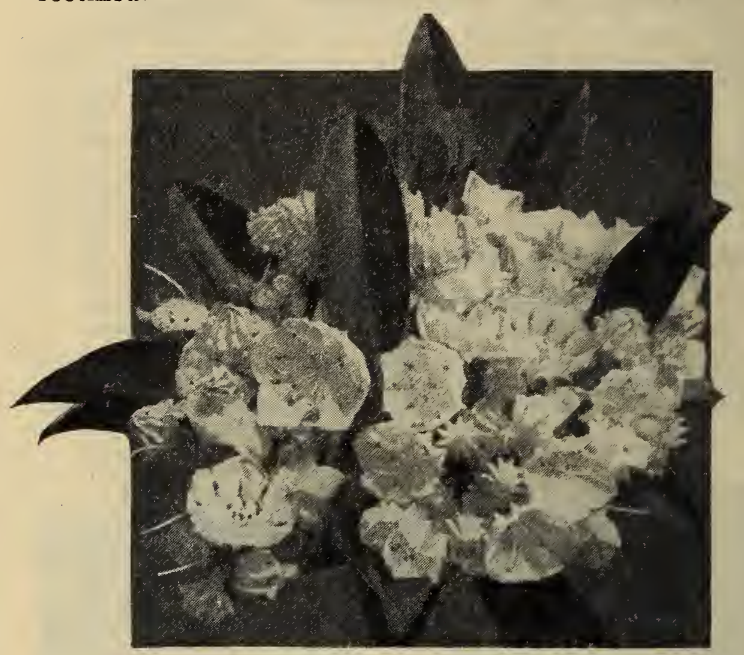

Kalmia latifolia (see pages 4 and 9 )

"And to paint these home pictures we need chiefly American material. We must face this deadly parallel:"

What We Really Plant

$70 \%$ European trees and shrubs and horticultural varieties.

$20 \%$ Chinese and Japanese.

$10 \%$ American.

Wilhelm Miller in "What England Can Teach Us About Gardening"

HARLAN P. KELSEY, owner, Salem, Mass., U. S. A.
What We Ought to Plant

$70 \%$ American trees and shrubs, i. e., native to America.

$20 \%$ Chinese and Japanese.

10\% European and horticultural.

J. Horacb McFarland Company, Harrisburg, $P_{A}$. 